\title{
TAF10 wt Allele
}

National Cancer Institute

\section{Source}

National Cancer Institute. TAF10 wt Allele. NCI Thesaurus. Code C52597.

Human TAF10 wild-type allele is located in the vicinity of $11 \mathrm{p} 15.3$ and is approximately 1 $\mathrm{kb}$ in length. This allele, which encodes transcription initiation factor TFIID subunit 10 protein, is involved in the regulation of transcription. 